\title{
An Analysis of the History and Trend of the Internationalization of Vocational Education in Tianjin
}

\author{
Li Jinhua \\ Tianjin Commerce vocational college \\ Tianjin, China \\ 300350
}

\begin{abstract}
Asa "National Innovation and Reform Demonstrative Region of Modern Vocational Education", Tianjin is one of the earliest, biggest and most influential regions for the Internationalization of Vocational Education. Based on an in-depth analysis of the connotation of the Internationalization of Vocational Education in many dimensions, this article reviews the development of the Internationalization of Vocational Education in Tianjin and predicts the future of Tianjin vocational education from "input" to "output".
\end{abstract}

Keywords-Tianjin;

Vocational

Education; Internationalization; History

\section{INTRODUCTION}

At present, internationalization has become the main trend of educational development. In 2010, "National Long-term Education Reform and Development Program (2010-2020)"proposed that multi-level and wide-region educational exchanges and cooperation should be carried out to improve the level of China's educational internationalization. As "National Innovation and Reform Demonstrative Region of Modern Vocational Education", Tianjin is one of the earliest and biggest regions of the Internationalization of Vocational Education, which have a wide influence. Based on the profound analysis of the connotation of the Internationalization of Vocational Education from many dimensions, this article reviews the development of the Internationalization of Vocational Education in Tianjin and predicts the trend of Tianjin vocational education from "input" to "output" in the future. It provides reference for the Internationalization of Vocational Education in China.
II. MUlTidimensional ANALYSIS OF THE CONNOTATION OF THE INTERNATIONALIZATION OF VOCATIONAL EDUCATION

The Internationalization of Vocational Education refers to the "The country's vocational education is based on localization and premise, facing the process of international exploit, development, and interaction" [1]. The interaction includes two meaning: First, through Learning from the advanced concept of vocational education in the world, it can be effectively integrated to improve the level of vocational education in the country. Second, by exporting the results of vocational education to the outside world, the impact can be expanded to enhance the international influence of the country's economy and industry. Since the concept of vocational education contains many elements, the internationalization of vocational education also has rich connotations. It needs to be analyzed from related various perspectives.

\section{A. Analysis of the Components of Vocational Education}

Vocational education includes a variety of elements, which determine the richness of the Connotation of the Internationalization of Vocational Education. Internationalization of training objectives Cultivate international advanced technical and applied talents "with broad international perspective and global responsibility awareness"[2]; Internationalization of professional standards--the introduction of vocational standards with international accreditation standards and academic qualifications for the development of native professional standards; The internationalization of the teaching environment has a practical base with international standards, and integrates the concept of international education for personnel training and curriculum development; Internationalization of teachers and students--teachers have the experience of study or work abroad, even with foreign nationality. Students have foreign nationality, or Graduates work abroad; Internationalization of school-running institutions-- the institutions between Chinese and foreign jointly run schools, foreign institutions establish vocational institutions in China, and domestic vocational institutions go abroad to establish educational and training institutions. In short, through the internationalization of various elements, a comprehensive international teaching system which integrate teaching, training, competition, and technology research is finally formed. 


\section{B. Analysis of the Activity Path of the Main Elements of Vocational Education}

As a development process, the development of internationalization of vocational education has two ways: the first one is to learn advanced vocational education experience and concepts of other countries, in order to absorb excellent foreign vocational education achievement, andex cellent vocational education talents for catching up with the level of foreign vocational education. Embodied in educational action, whether "going out" or "inviting in", it is an "input" process of learning from high-level countries. The second way is disseminating the concept and results of excellent vocational education to low-level vocational education abroad. We can establish vocational education, train institutions in foreign countries, exported domestic teaching resources to foreign countries, share excellent vocational education achievements with foreign countries and attracting teachers and students from foreign vocational schools to study in the country. Embodied in education actions, "going out" or "inviting in" are all the "output" processes for expanding the international influence of China's vocational education. Whether "input" or "output", it is a process of interaction between the two parties. "Input" is to raise the level and the "output" can help us find better partners for achieving higher levels of cooperation and accelerating the development of vocational education.

\section{THE DEVELOPMENT OF THE INTERNATIONALIZATION OF VOCATIONAL EDUCATION IN TIANJIN}

In Modern time, as a port city, Tianjinis developing foreign business and industry. Vocational education began to sprout. Nowadays, Tianjin has become one of the earliest and most advanced areas on the Internationalization of Vocational Education, and its process has three major upsurges.

\section{A. Full Reference to the Western Modern Educational Model in the Late Qing Dynasty}

In the late Qing Dynasty, Tianjin as the center of the Westernization Movement in the North of China, established a series of foreign affairs schools for teaching foreign languages, technology, and military based on the standards and requirements of the Western industry, and cultivated talents who master Western languages and modern military technology. Different from the private schools that were specially designed to take the Imperial Examination, these modern schools introduced teachers who possessed modern knowledge and skills, used western teaching systems, set up modern specialties such as telegrams, English, railway engineering and modern medicine. They compiled teaching content according to Western curriculum standards. In order to learn from the Western teaching model combined with theory and practice, Tianjin's vocational education began to sprout in the form of modern education for enhancing skills. In the early 20th century, Tianjin became a trading port for various countries. With the development of industry, vocational education in Tianjin began to expanse in scale, quantity and specialized subject, and initially formed modern vocational education system including primary, intermediate, and advanced levels.
Nowadays, the level of the Internationalization of Vocational Education in Tianjin is improving rapidly. Many schools hired foreign experts or students graduating abroad as teachers. In 1904, Tianjin set up internship workshop. "There is a lecture hall in the factory."[3] Just like the current training base of "school- factory cooperation", some schools selected outstanding students to study and practice abroad. However, during that period, many school almost imported the culture of advanced foreign technology and professional standards directly and absorbed all aspects of Western education content, method sand ideas. Its teaching model has also been copied from foreign school sand actually integrated with traditional education in ideas and good teaching experience.

\section{B. Reference to the Soviet Union's Vocational Education System and Foreign Educational Concepts at the Beginning of the Liberation}

In the early days of the liberation, the government of Tianjin took over all vocational schools established in old society, and increased school categories. Since the planned economy is implemented in recent years, all enterprises and institutions are collectively owned, the training direction and management of vocational education are unified across the country. At that time, vocational education throughout the country mainly studied the experience of the world's two most powerful countries in the process of internationalization.

The first refer to the experience of the former Soviet Union and position vocational education as training medium technical talent. According to the mechanism of the Soviet Union, the technical talents at that time included technical cadres and skilled workers. Therefore, the education department changed all pre-liberation vocational schools to full-time specialized middle schools to train intermediate technical management talents. According to production needs, the labor department adjusted the technical training classes and technical schools that used to train the employee sand set up technical education aimed at cultivating middle-level skilled workers. Medium vocational education and technical education "take the principle of running schools, enrollment, and distribution, that highly imitated Soviet" [4].

Second, in the 1950s, enlightened by American, the education of part-time work and part-time reading was carried out. It combined with studying and working. At that time, Tianjin conducted a large-scale pilot project, Factories and enterprises organized part-time work and part-time reading schools, Full-time specialized middle schools and technical schools too. These part-time work and part-time reading schools cultivated a large number of excellent Technical talents Comrade Liu Shaoqi put forward the "part-time school education system and part-time factory labor system" [5] based on the successful experience of Tianjin. However, with the arrival of the Cultural Revolution, two institutional theory was interrupted. 


\section{Exchanges and Cooperation with Developed Countries in the Early Period of Reform and Opening up.}

After Reform and Opening Policy, with the call of "education should face to the world", being restored, vocational education in Tianjin has embarked on the journey of internationalization and has really sat down to learn from the world. In 1982, Tianjin First Light Industry School was the first vocational school in China to receive funding from the United Nations Development Administration. It cooperated with the United Nations to launch the CPR/81/039 Enhancing Vocational and Technical Education Project. The United Nations invested US\$800,000 to "enrich and improve facility in major of Daily chemistry and light industrial machinery, as well as improved the level of teachers inschool [6],which has opened up the pace of the Internationalization of Vocational Education in Tianjin after Reform and Opening Policy. During the two years of the project, Tianjin First light industry school obtained chances in contact with the world "Exploration of Experimental Equipment, Gathering Information on Technical Education" [7], making educational concepts and teaching facilities goes further.

Since then, the degree of the Internationalization of Vocational Education in Tianjin has continued to deepen more: First, since the 1990s, Tianjin has started to open up practical training bases overseas. Second, the Tianjin government has begun to try to joint educational activities with developed countries. The most typical cases is in 1985, the governments of Tianjin and of German jointly established Tianjin Sino-German Modern Industrial Technology Training Center, "training mediate technical cadres and technical workers for major technical cooperation projects between the two countries, as a demonstration project for systematic dual-system vocational training between China and Germany to Promote nationwide" [8]. After 30 years of development, the training center has developed into a University of Applied Sciences in Tianjin and leading in vocational education in our country now.

\section{Constructing International Innovation Demonstration since the New Century}

In the 21th century, China officially joined the WTO. In the face of economic globalization and international competition, vocational education in Tianjin has accelerated the pace of internationalization. In2005, Tianjin became "National Innovation and Reform Demonstrative Region of Modern Vocational Education" and was charged with the important mission of "raising the level of the Internationalization of Vocational Education and establishing a new window for international cooperation in vocational education" [9] and strived to "develop multiple-types, height-Standards and wide-ranging exchanges and cooperation in vocational education" [10] and began to explore internationalization first.

Firstly, an international communication platform was created. Since 2008, Tianjin Government and Ministry of Education of china have jointly organized the National Vocational College Skills competition. The setting of items and content of competition are based on the international development of the industry. Competition venues and protocols adopt advanced international standards. With the largest number of companies, regions, schools and students participate, it became the most influential vocational education events, various international conferences held during the competition, various international competitions and meetings attract experts from Germany, Spain, India, Malaysia, Thailand, Laos, and other countries to participate in. The international level of the competition has been continuously improved.

Secondly, international professional standards was developed. Since 2012, a number of vocational colleges in Tianjin united and selected 50 specialties in the fields of advanced manufacturing, emerging industries, and modern service, developed vocational teaching standards. "In contrast to the 'lowest' vocational teaching standards developed in the past that apply to all vocational colleges, the international vocational teaching standards are aimed at the world's highest level of vocational education teaching standards, and introduce international advanced Process flow, products Standards, technical standards, and service standards into teaching content"[11].At present, Tianjin has established 131 pilot classes in many vocational colleges relying on 50 international vocational teaching standards, the number of pilot students is 4,467 ,"a group of localized technical talents with international perspectives and international rules are becoming the backbone of various technical positions" by pilot training [12]

Thirdly, many international training bases were built. First, in order to complete the gradual learning process of "training from simple skill to comprehensive skills"[13],specialty equipment was introduced according to international standards and construction concepts, more than 500 training bases are established in vocational schools. 8 training bases for shortage skills are established. Second, it has built up practical training bases overseas. Internship abroad becomes commonplaces.

Fourthly, international students and teachers resources were introduced. At present, "Tianjin has established deeply international exchanges and cooperation relationships with governments and institutions in more than 20 countries and regions" [14]. Many vocational teachers and students regularly visit foreign vocational schools for in-depth exchanges and visits. Many schools established "Expert Resource Bank for Foreign Experts", and employed foreign teachers to conduct English and specialty teaching activities.

\section{THE FUTURE TREND OF THE INTERNATIONALIZATION OF VOCATIONAL EDUCATION IN TIANJIN}

At present, with the implementation of One Belt and One Road National Development Strategy and Industrial Development Going Out Strategy, in the global urban system, "Tianjin, as an international port city and an important node between China and the world, must represent the country to participate in the global Industry competition"[15].While the development platform for modern manufacturing in Binhai New Area of Tianjin has become increasingly solid, Tianjin's economic functions and development potential have also been given new meaning. Tianjin is becoming the opening portal of northern China into "the most influential and competitive force in Northeast Asia". [16]Today, Tianjin, as the "National Innovation and Reform Demonstrative Region of Modern Vocational Education", takes the service of national development strategies and the needs of regional economic and social development as an important task. The development of 
vocational education in Tianjin will assume the responsibility of providing talent protection for the overseas development of the industry and play a major role in creating a clickable role for Chinese corporate image brands. Output from product to technical, service, and education will become the best development path for effective delivery of China's production capacity.

\section{A. It is necessary to improve itself, but it must be continuously exported}

At present, vocational education in China and vocational education in Tianjin still need to learn developed countries. With the opportunity to host the National Vocational College Skills Contest, Tianjin has achieved connection with the World Skills Contest in various aspects such as the item, equipment, content and criteria, the level of Contest has continuously improved. At the same time, Tianjin is striving to build the Contest as a platform to continuously output vocational standards abroad. Since 2010,the item of "Automatic Line Installation and Commissioning", "CNC Machine Tool Assembly, Commissioning and Maintenance" have been introduced into the ASEAN Skills Contest; since 2012,the three-dimensional bilingual textbooks of "Automatic Production Line Installation and Commissioning", and" Engineering Practice Innovation Project Tutorial" had been compiled and published. The competition results have been continuously transformed into teaching resources, which have been introduced by ASEAN countries as practical training materials; Since 2015, Tianjin's vocational colleges had begun to set up teaching and training center--"Luban Workshop "in Thailand, India, and the United Kingdom, the "Chinese Standard" is gradually into international by vocational education.

\section{B. Export from education to cultural identity}

In the process of exporting vocational education concepts, models, and equipment resources, it is accompanied by the collision of traditions, cultures and customs between China and the whole world. Since 2015,the Mechatronics Major of Tianjin Sino-German University of Applied Sciences, the Hotel Management Major of Tianjin Commerce vocational college, the Marine Engineering Major of Tianjin Maritime College, and the Railway Major of Tianjin Railway Vocational College began to recruit Thai International students have full-time academic education. In the three years of study in China, they not only need to learn professional skills, but also master the profound Chinese culture and the spirit of excellence. The "Luban Workshop" along with the "One Belt and One Road" construction goes out of the country, it uses the name of Luban, a great artisan in ancient China. Its logo "designed with the Chinese traditional concept of the Tianyuandifang, used the auspicious cloud and the book combination pattern as the background" [17], embodying the spirit of Chinese artisan. With exporting high-quality vocational education standards, it is also the across of "exporting Chinese culture, telling Chinese stories, and enhancing national cultural influence" [18], sharing Chinese wisdom and spirit with the world.

\section{CONCLUSION}

Reviewing the development course of Tianjin's vocational education, its international development has experienced the input process of learning from the developed countries, the output process of sharing the country's outstanding vocational education achievements with the world, using two types of "incoming" and "going out". The concept of vocational education is continuously updated, and the mechanism is continuously improved. Tianjin, as China's economic development center, as the leader in vocational education reform and innovation, with China's manufacturing coming into the world, its vocational education will not only go out, but also go farther and better; with the Chinese standards go abroad, the Chinese element will eventually all over the world.

\section{ACKNOWLEDGMENT}

This article is the mid-term achievement of Tianjin Education Science 13th Five-Year Plan Vocational Education General Project "Research on the History of Reform and Development of Tianjin Vocational Education since Reform and Opening-up" (Project approval No: VE3164), and Tianjin Education Science 13th Five-Year Plan Vocational Education Special Project "Research on National Vocational Education Development Museum Construction" (project approval No: VESP1001)

\section{REFERENCES}

[1] Xu Meiyin. Research on the Internationalization of Higher Vocational Education in China [J]. Journal of Yangzhou Vocational University, 2009(2):56-59.

[2] HouXingshu.Connotation, situation and promotion tactics of internationalization of vocational education [J]. Chinese Vocational and Technical Education, 2012(21):46-50.

[3] Zhang Damin. History of Tianjin Education [M].Tianjin: Tianjin People's Publishing House, 1993:127.

[4] Tian Yongquan.Vocational and technical education after the liberation of Tianjin [M]//Tianjin Adult Education Vocational and Technical Education History (first series), 1987: 25.

[5] Zheng Kaixuan. On Liu Shaoqi's Thoughts of"Two Labo Systems"and"Two Educational Systems" [J].Party History and Literature Court, 2015(5):32-34

[6] Ministry of Education. China Education Yearbook (1982-1984) [M].Beijing: People's Education Press, 1984:309.

[7] Tianjin General Education Yearbook Editorial Board. Tianjin General Education Yearbook (1984) [M].Tianjin: Tianjin Education Press, 1984: 212

[8] Liu Guishun.Tianjin Adult Education and General Secondary Education Memorabilia [M]. Tianjin: Baihua Literature and Art Publishing House, 1994:430.

[9] Tianjin Government.Notice on Printing and Distributing the Implementation Plan for the Construction of National Vocational Education Reform Pilot Zone (ZiZhengfa [2006] No.24) [Z] 2006-03-23.

[10] Tianjin implements the "eight projects"to promote the construction of national vocational education reform and innovation demonstration area [EB/OL]. (2015-09-08)[2015-10-1]. http://www.moe.edu.cn /jyb_xwfb/s6192/s222/moe_1733/201509/t20150908_206483.html.

[11] Jiang Dayuan. Discussion on the development of international professional teaching standards [J].Chinese Vocational and Technical Education, 2013(9):11-15.

[12] The Five Industries Linked to the New Path of Vocational Education [N] Tianjin Daily, 2016-8-14. 
[13] Build a digital factory to help personnel training [EB/OL]. (2013-05-29)[2013-06-01]. Northern Net. http://www.enorth.com.cn.

[14] Yang Yan. Exploring Overseas Export Model of Vocational Education in Tianjin [J]. Tianjin Academy of Education, 2016(5):29-31.

[15] Zhu Erjuan. To enhance the internationalization level of Tianjin Binhai New Area [M]. Social Sciences Academic Press, 2015:91.

[16] Institute of Industrial Economics in Nankai University. Industrial Development Report of Tianjin Binhai New Area [M].Economic Management Press, 2012:16.

[17] RuiFuxiang, Yu Lanping.The new fulcrum of international cooperation in vocational education in Luban Workshop [M]. Beijing: China Railway Publishing House, 2017: 73.

[18] Song Ronghua, HaoYaohua. The One Belt One Road Strategy leads Chinese companies "goingout" [EB/OL] (2014-12-27) [2014-12-30].http://world.people.com.cn/n/2014/1227/c1002-26285988. html. 